\title{
Default in plasma and intestinal $\lg A$ responses during acute infection by simian immunodeficiency virus
}

Nada Chaoul ${ }^{1,2}$, Chantal Burelout ${ }^{1,2}$, Sandrine Peruchon 1,2,3, Beatrice Nguyen van Buu ${ }^{4,5}$, Pascale Laurent ${ }^{4,5}$, Alexis Proust ${ }^{6,7}$, Martine Raphael ${ }^{6,7}$, Olivier Garraud ${ }^{3}$, Roger Le Grand ${ }^{1,2}$, Sophie Prevot ${ }^{4,5}$ and Yolande Richard ${ }^{1,2,8,9^{*}}$

\begin{abstract}
Background: Conflicting results regarding changes in mucosal IgA production or in the proportions of IgA plasma cells in the small and large intestines during HIV-infection have been previously reported. Except in individuals repeatedly exposed to HIV-1 but yet remaining uninfected, HIV-specific lgAs are frequently absent in mucosal secretions from HIV-infected patients. However, little is known about the organization and functionality of mucosal B-cell follicles in acute HIV/SIV infection during which a T-dependent IgA response should have been initiated. In the present study, we evaluated changes in B-cell and T-cell subsets as well as the extent of apoptosis and class-specific plasma cells in Peyer's Patches, isolated lymphoid follicles, and lamina propria. Plasma levels of IgA, BAFF and APRIL were also determined.

Results: Plasma lgA level was reduced by $46 \%$ by 28 days post infection (dpi), and no IgA plasma cells were found within germinal centers of Peyer's Patches and isolated lymphoid follicles. This lack of a T-dependent IgA response occurs although germinal centers remained functional with no sign of follicular damage, while a prolonged survival of follicular CD4+ T-cells and normal generation of IgG plasma cells is observed. Whereas the average plasma BAFF level was increased by 4.5 -fold and total plasma cells were 1.7 to 1.9-fold more numerous in the lamina propria, the relative proportion of IgA plasma cells in this effector site was reduced by 19\% (duodemun) to 35\% (ileum) at $28 \mathrm{dpi}$.

Conclusion: Our data provide evidence that SIV is unable to initiate a T-dependent IgA response during the acute phase of infection and favors the production of lgG (ileum) or lgM (duodenum) plasma cells at the expense of IgA plasma cells. Therefore, an early and generalized default in IgA production takes place during the acute of phase of HIV/SIV infection, which might impair not only the virus-specific antibody response but also IgA responses to other pathogens and vaccines as well. Understanding the mechanisms that impair IgA production during acute HIV/SIV infection is crucial to improve virusspecific response in mucosa and control microbial translocation.
\end{abstract}

Keywords: Mucosal B-cell response, IgA, HIV/SIV, Germinal centers, BAFF, Terminal ileum

\section{Background}

The gastrointestinal tract is a privileged site for both HIV$1 /$ SIV replication and extensive $\mathrm{CD}^{+}{ }^{+} \mathrm{T}$-cell depletion at all stages of the pathogenic infection [1,2]. One of the physiological roles of the gastrointestinal tract in immunological defense is to produce large amounts of IgA that contribute to the protection of the intestinal mucosa from

\footnotetext{
*Correspondence: yolande.richard@inserm.fr

'Commissariat à l'Energie Atomique (CEA), CEA, Institut des Maladies

Emergentes et Thérapies Innovantes Service d'Immuno-Virologie, CEA,

Fontenay-aux Roses, F-92260, France

${ }^{2}$ Université Paris-Sud, Orsay, F-91060, France

Full list of author information is available at the end of the article
}

pathogens [3]. IgA are produced from plasmablasts (plasma cell precursors) generated in germinal centers (GC) of Peyer's patches (PP) and mesenteric lymph nodes that constitute major inductive sites of T-dependent IgA antibodies. Both T-cell help and local production of cytokines participate in T-dependent IgA production [4-7]. IgA class switching also occurs in isolated lymphoid follicles (ILF), which have a cellular composition similar to PP-associated follicles and constitute dynamic lymphoid structures that develop in response to chronic infection or inflammation [8-10]. In addition to the canonical TGF $\beta 1$ IgA switch factor, IL10, IL21, B-cell Activating Factor of the

\section{Biomed Central}


TNF Family (BAFF) and A Proliferation-Inducing Ligand (APRIL) are also key factors involved in both T-dependent and T-independent immunoglobulin class switching $[9,11]$. These latter cytokines most likely account for IgA production in children with defective CD40L $[12,13]$. In contrast to humans, only one IgA isotype is found in macaques, with a structure resembling that of human IgA2 $[14,15]$.

Although conflicting results exist concerning the presence of HIV-specific IgA in genital secretions of women repeatedly exposed to HIV-1 but yet remaining uninfected [16-19], HIV-specific IgA are generally absent or present at very low levels in plasma and mucosal secretions of chronically HIV-infected patients [20-24]. In contrast to other encountered mucosal microbial infections, HIV-1 infection preferentially leads to potent IgG responses in any body fluids. Decreased levels of IgA in intestinal fluids associates with reduced proportions of IgA plasma cells within the lamina propria (LP) of the duodenum and colon of chronically HIV-infected patients [25]. In AIDS patients, depletion of IgA plasma cells in the small intestine also correlates with decreased secretion of IgA in saliva [22]. In supernatants of short-term cultured duodenal biopsies from SIV-infected macaques, Schafer at al. described a decrease in total IgA and a lack of SIV-specific IgA for up to 6 months post-infection [26]. However, measuring HIV/SIV-specific and total antibodies in intestinal and vaginal secretions by ELISA constitutes a technical challenge [27], likely contributing to conflicting results. Moreover, IgA secretion is highly dependent on the integrity of epithelial cells, which is frequently impaired during acute and chronic HIV/SIV infections [28-30]. Overall, the lack of IgA in intestinal fluids of chronically HIV-infected patients or SIV-infected macaques can be explained by a default in shedding, impaired homing of IgA plasmablasts to LP or their impaired terminal differentiation into plasma cells. In addition, recent data of $\mathrm{Xu}$ et al. suggested that an impaired isotype switching towards IgA occurs in inductive sites [31], preventing the generation of IgA plasmablasts.

Here, we have examined changes in the proportions of IgA vs. IgG and IgM plasma cells within the inductive sites (germinal centers of B-cell follicles) and effector site (LP) of the small intestine (duodenum and terminal ileum) of acutely SIV-infected macaques to determine at which step the generation of IgA plasma cells was impaired. Our data reveal a progressive decrease in plasma IgA after SIV infection, associated with a lack of IgA plasma cells within GC of PP and isolated lymphoid follicles while functional GC can still give rise to IgG plasma cells. Whereas the densities of total plasma cells increased in the LP, the relative proportion of IgA plasma cells decreased. Altogether, these findings suggest that SIV is unable to initiate a T-dependent IgA response during the acute phase of SIV infection despite prolonged survival of follicular $\mathrm{CD} 4^{+} \mathrm{T}$-cells.

\section{Results}

Increased B-cell homing to the intestinal mucosa during the acute phase of infection

Both changes in levels of plasma viral load and $\mathrm{CD} 4^{+} \mathrm{T}$-cell count followed similar kinetics and range in all macaques. By 11-12 dpi, plasma viral load peaked with a median value of $7.36 \log _{10}$ SIV RNA copies/ml before decreasing to 5.78 $\log _{10}$ SIV RNA copies/ml on 28 dpi (Figure 1A). As compared to its value before infection, the median blood $\mathrm{CD} 4^{+}$ T-cell count reached its lowest value on 11-12 dpi (76.9\% decrease, $p=0.0004$ ), coincident with the peak in viral load (Figure 1B). In agreement with our previous observations [32], SIV-infection rapidly induced B-cell accumulation in the intestinal mucosa as compared to controls (Figure 1C, 1D). However, the intensity of B-cell infiltration was variable among SIV-infected animals and even at different sites of the intestinal mucosa within one animal (Figure 1E and 1F). The median number of B-cell areas per $\mu \mathrm{m}^{2}$ of total duodenal mucosa increased by 1.2-fold and 1.8-fold on 14 and $28 \mathrm{dpi}$, respectively (Figure 1E) whereas it increased by 1.1-fold and 1-fold in the terminal ileum, respectively (Figure 1F). Despite high numbers of isolated B-cell follicles in terminal ileum of SIV-infected animals, the concomitant increase in mucosal thickness lowers the frequency value. (Figure 1D, right panel). The development of GC within Bcell follicles constitutes an independent marker of B-cell activation. Within the intestinal mucosa of SIV-infected animals, B-cell follicles rapidly developed GC, with 39\% of duodenal follicles containing GC as compared to $3 \%$ in controls. Whereas an average of $21 \%$ ileal B-cell areas contained GC in controls, 34\% and 44\% of them contained GC at 14 and $28 \mathrm{dpi}$, respectively.

These data evidence a consistent B-cell activation in intestinal mucosa during acute SIV infection, with an early development of GC in intestinal B-cell follicles, which is indicative of the initiation of TD B-cell response. However, SIV-specific antibodies are only detectable in plasma from 21 dpi on in these animals [29].

\section{Preferential increase in IgG plasma cells within GC during acute SIV infection}

Because CD20 expression is rapidly lost during terminal Bcell differentiation, human plasma cells and their immediate precursors are generally detected using CD19, CD38 and CD138 mAb. While CD19 expression progressively decreases, CD38 expression begins to be upregulated on human plasmablasts and CD138 expression characterizes late stages of plasma cell maturation [33]. The detection of macaque B-cells engaged into terminal differentiation is limited by the lack of suitable reagents: human CD19 and human CD138 mAb possess limited and no cross-reactivity, 


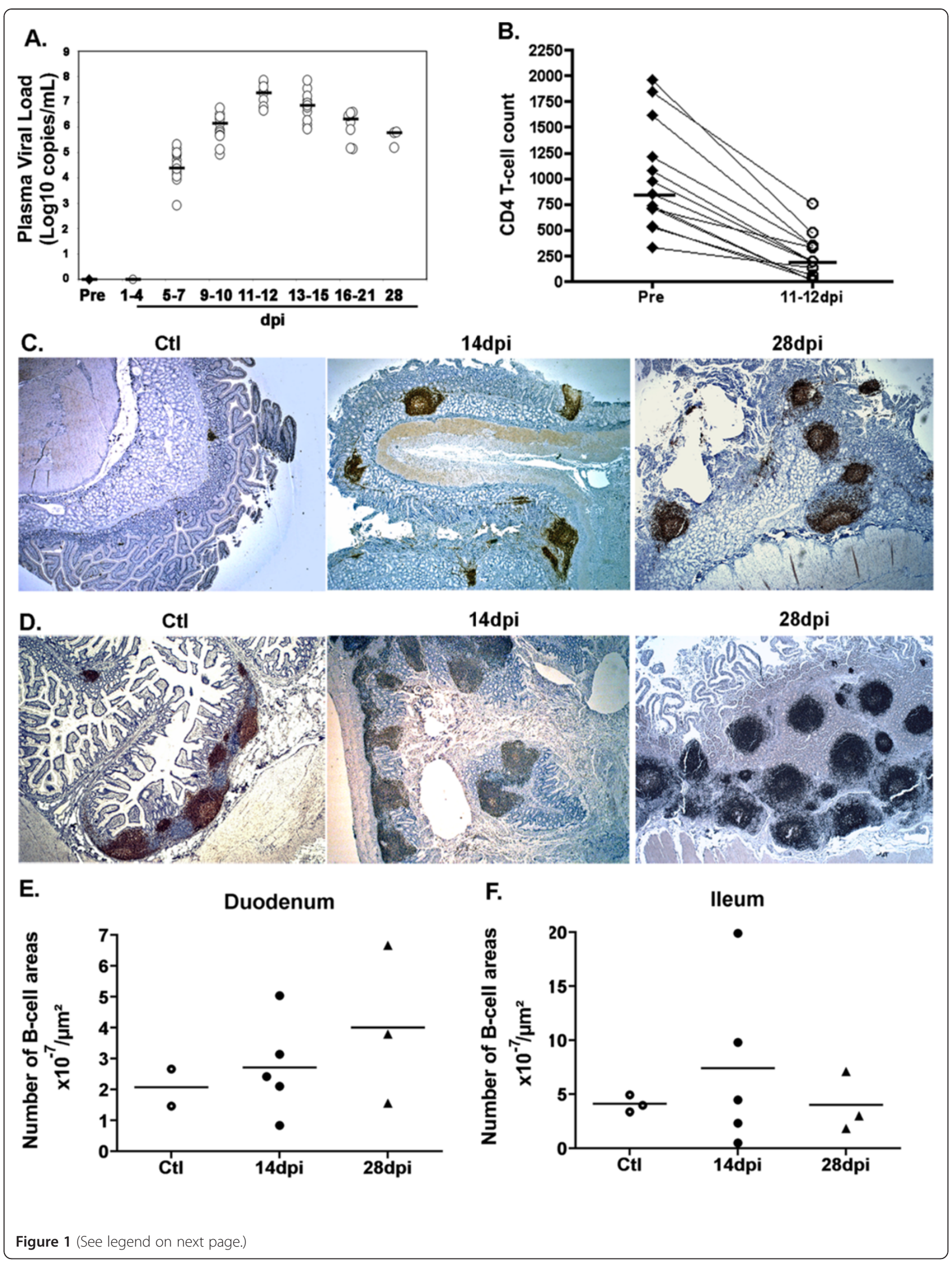


(See figure on previous page.)

Figure 1 Increased number of B-cell areas in the intestinal mucosa in acutely SIV-infected macaques. (A) For each of the 13 SIV-infected macaques, viral load was measured in plasma before infection (Pre; filled circles) and every 3 dpi (open circles). Results are expressed as Log 10 copies $/ \mathrm{mL}$ and bars represent median values. (B) $C D 4^{+}$T-cells were quantified in whole blood collected from each macaque before infection and every 3 dpi. For each animal, CD4 ${ }^{+}$T-cell counts before infection (filled circles; $n=13$ ) and at 11-12 dpi (open circles, $n=13$ ) are shown. Results are expressed as cells $/ \mu \mathrm{L}$ and bars represent median values. *** $p=0.0004$ (Wilcoxon test) (C-D) Staining by CD20 mAb of sections from duodenum (C) and terminal ileum (D) of one representative non-infected macaque ( $\mathrm{Ctl}, \mathrm{n}=3)$ and macaques infected for 14 (14 dpi, $\mathrm{n=5}$ ) or 28 days (28 dpi, $\mathrm{n}=3$ ). Magnification $\times 25$ for all panels $(\mathbf{E}-\mathbf{F})$ The number of $\mathrm{CD}_{2} \mathrm{O}^{+} \mathrm{B}$-cell areas per section was divided by the surface of the total mucosa. Results are expressed as B-cell areas $\times 10^{-7} / \mathrm{um}^{2}$. Each symbol corresponds to one animal. Bars represent median values for each group.

respectively, while human $\mathrm{CD} 38 \mathrm{mAb}$ are unable to discriminate plasma cells from other simian B-cells subsets (data not shown). We thus evaluated changes in plasma cells by immunohistochemistry using alternative markers: IRF4/MUM-1 and cytoplasmic Ig. High IRF4/MUM-1 protein expression is a hallmark of normal plasma cell differentiation and a major marker of myeloma cells [34].

We found rare IgA plasma cells in GC of the duodenal mucosa of both control and SIV-infected macaques. In contrast, total (stained by IRF4 mAb) and IgG plasma cells per GC were 1.1- and 1.4-fold more numerous in SIV-infected macaques on 28 dpi than in controls (Figure 2A). In terminal ileum, the median number of total plasma cells increased by 1.9 - and 3.1 -fold on 14 and $28 \mathrm{dpi}$, respectively. This increase was essentially due to increased numbers of IgG plasma cells per GC, with a 3.8- and 7.2-fold increase on 14 and $28 \mathrm{dpi}$, respectively (Figure 2C). Therefore, SIV-infection preferentially promotes an IgG response within GC of the small intestine as in spleen and mesenteric lymph nodes [32].

\section{SIV infection modifies the ratio of IgA versus IgM or IgG plasma cells within the LP}

Comparison between median values of each group showed that densities in total plasma cells in the duodenal LP were 1.6- and 2.6-fold higher on 14 and $28 \mathrm{dpi}$, respectively, than in controls (Figure 3A). However, a variable increase in the density of each class-specific plasma cells occurred on 14 and 28 dpi: 2.6- and 5.9-fold increase for IgM plasma cells, 1.4- and 2.1-fold increase for IgA, and 1.4- and 1.6-fold increase for IgG, respectively (Figure $3 \mathrm{~B}$ ). Therefore, higher proportions of IgM plasma cells were observed on 28 dpi (36\% vs. $16 \%$ in controls, 2.2 -fold) at the expense of IgG (13\% vs. $21 \%$ in controls) and IgA ( $52 \%$ vs. $63 \%$ in controls) plasma cells (Additional file 1: Figure S1A).

In the terminal ileum, the density of total plasma cells also increased in the LP by 1.7- and 4.9-fold on 14 and 28 dpi as compared to controls (Figure 3C). As also compared to controls, the density of IgA plasma cells increased by 1.4- and 3.1-fold on 14 and $28 \mathrm{dpi}$, that of IgG by 2.5 - and 15 -fold and that of IgM by 2.2 - and 8.3 -fold, respectively.
These changes resulted in higher proportions of IgG plasma cells at $28 \mathrm{dpi}(21.5 \%$ vs. $7 \%)$ at the expense of IgA plasma cells (43\% vs. 66\%) (Additional file 1: Figure S1B). These data show that SIV-infection favors the generation of IgM (duodenum) or IgG (ileum) rather than IgA plasma cells in the LP of the small intestine.

Taken altogether these data suggest a biased isotype class switching or an impaired survival of IgA plasma cells in the intestinal mucosa of acutely SIV-infected macaques.

\section{Differential survival of $\mathrm{CD}^{+}{ }^{+} \mathrm{CD} 45 \mathrm{RO}^{+} \mathrm{T}$-cells in $\mathrm{GC}$, follicular T-cell zones and LP}

We next examined T-cell changes in the LP and inductive sites (PP and ILF) of the small intestine of SIV-infected macaques. In the duodenum of control animals, we observed numerous $\mathrm{CD}_{4}^{+}$(Figure $4 \mathrm{~B}$ ) and $\mathrm{CD}_{45 \mathrm{RO}^{+}} \mathrm{T}$ cells (recognized by the OPD4 clone) (Figure 4C,D) distributed throughout the LP as well as in follicular T-cell zones. As compared to control macaques, $\mathrm{CD}_{45 \mathrm{RO}^{+}} \mathrm{T}$-cell density was $80 \%$ lower in the follicular T-cell zones at $14 \mathrm{dpi}$ (Figure 4F). The well-defined line of $\mathrm{CD}^{+}$and $\mathrm{CD} 45 \mathrm{RO}^{+}$ T-cells, visible at the interface between mucosa and muscularis mucosae in controls (Figure 4B, C, left panels, arrow) was no more detectable in SIV-infected macaques, except near and above B-cell follicles (Figure 4C, arrow); indeed $\mathrm{CD}_{45 \mathrm{RO}^{+}} \mathrm{T}$-cell density was decreased by $78 \%$ and $88 \%$ in muscularis mucosae at 14 and $28 \mathrm{dpi}$, respectively (Figure 4G). In contrast, the frequency of $\mathrm{CD}^{4} 5 \mathrm{RO}^{+} \mathrm{T}$-cells within the GC of duodenal B-cell follicles did not decrease before $28 \mathrm{dpi}$ (44\% decrease) (Figure 4E). As shown by $\mathrm{CD} 23$ and Ki67 staining, the polarization of GC was preserved until 28 dpi (Additional file 2: Figure S2).

In the terminal ileum, the median $\mathrm{CD}_{4} 5 \mathrm{RO}^{+} \mathrm{T}$-cells density decreased by $59 \%$ and $73 \%$ respectively at 14 and $28 \mathrm{dpi}$ in follicular T-cell zones, and by $84 \%$ in muscularis mucosae at $14 \mathrm{dpi}$, as compared to controls (data not shown). Concomitantly, a 1.8-fold increase in CD45RO ${ }^{+} \mathrm{T}$ cells was observed within the GC of ileal B-cell follicles on 14 dpi. Thus, in contrast to follicular T-cell zones and muscularis mucosae where the depletion in $\mathrm{CD}_{4}^{+} \mathrm{T}$-cells rapidly progressed from $14 \mathrm{dpi}$ on, $\mathrm{CD} 4^{+} \mathrm{CD} 45 \mathrm{RO}^{+} \mathrm{T}$-cells accumulated within GC of mucosal B-cell follicles at 14 dpi. 


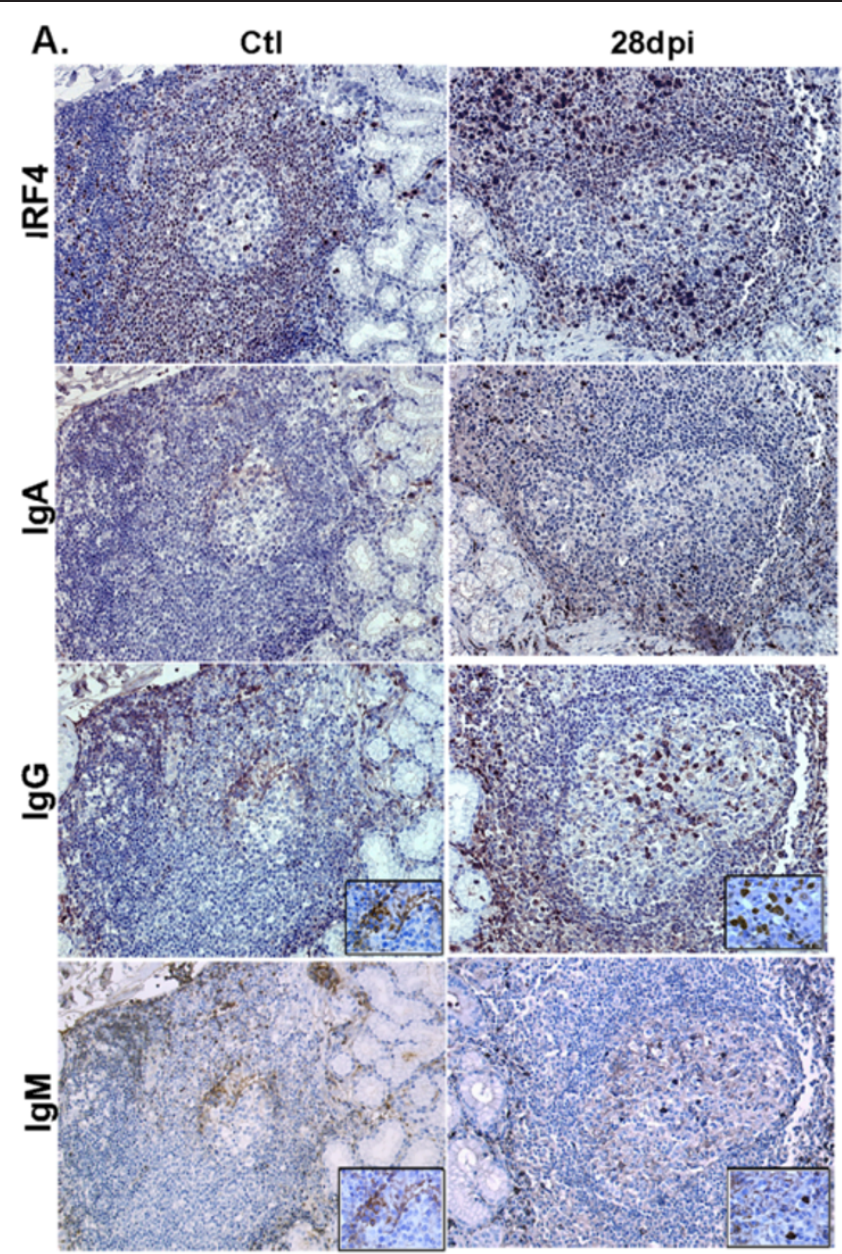

\section{B. Duodenum}

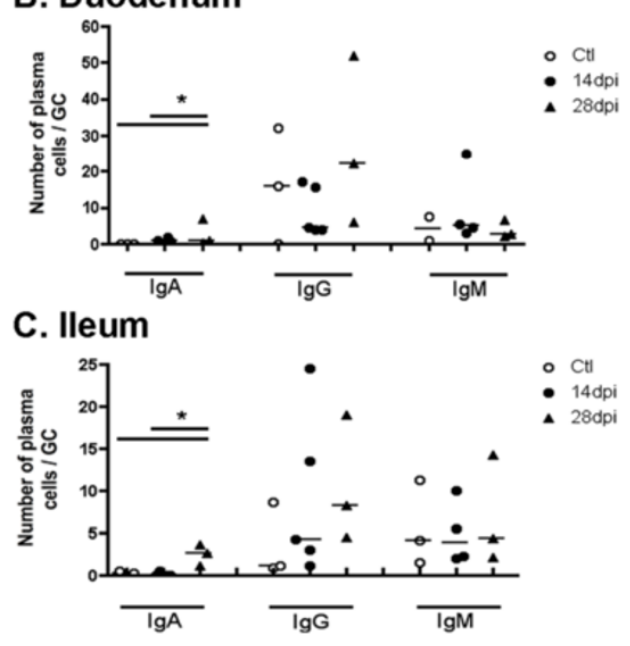

Figure 2 Acute SIV infection induces a dominant IgG/M over IgA response in GC. (A) Duodenal sections from controls (Ctl left panels) and macaques infected for 28 days (28 dpi, right panels) were stained with IRF4 mAb, IgA, IgG and IgM polyclonal Ab. Staining of one representative section for each group of macaques is shown. Magnification x200 and x1000 for enlarged images. (B-C) Each symbol represents the mean number of IgA, IgG and IgM plasma cells per GC in duodenum (B) and terminal ileum (C) in one macaque. Bars represent median values for each group. 


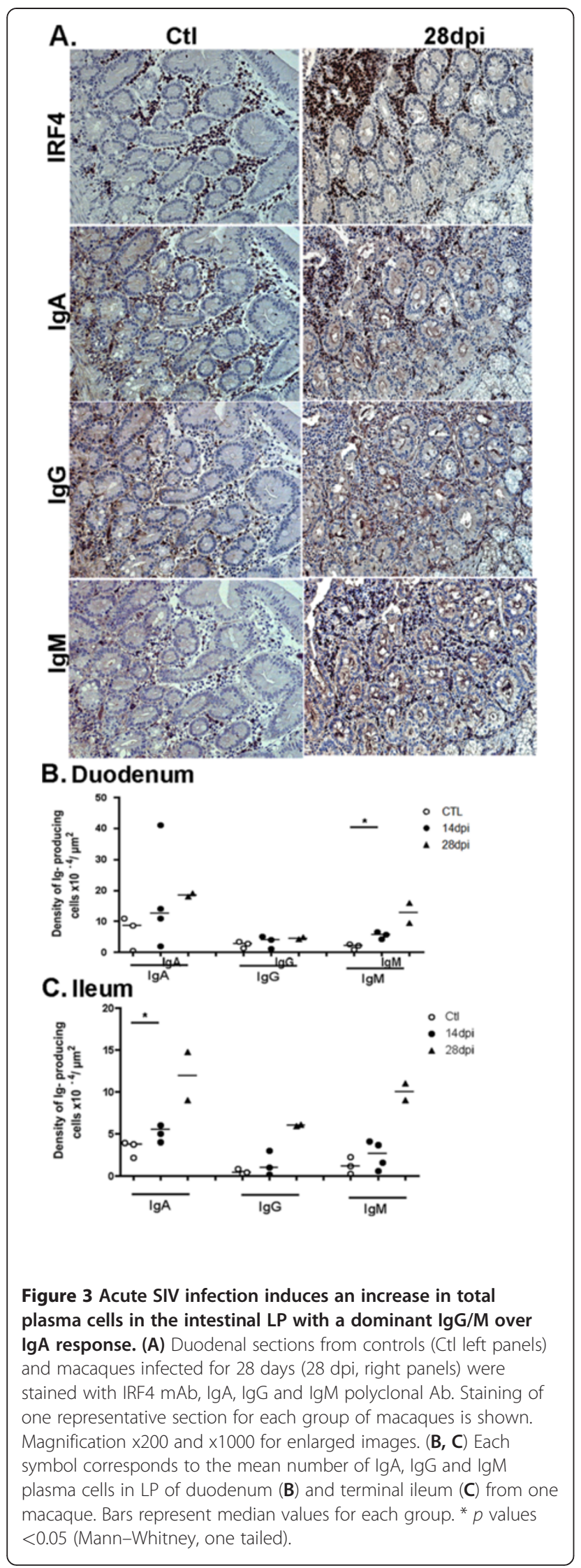

\section{Distinct kinetics of apoptosis in GC, follicular T-cell zones and LP}

Because increased apoptosis might contribute to the paucity of IgA plasma cells, we examined the expression of the cleaved caspase-3, a key mediator of apoptosis shared by membrane- and mitochondrial-mediated pathways. In the duodenal mucosa, no cleaved caspase $-3^{+}$cells were found within GC or follicular T-cell zones of control macaques (data not shown). In the follicular T-cell zone, the median density increased by 6.5 -fold between 14 and 28 dpi (Figure 5A-F, 5 G) whereas the median number of cleaved caspase-3+ cells is 10.5 and 3.2 cells/GC at 14 and $28 \mathrm{dpi}$, respectively (Figure $5 \mathrm{H}$ ). In the terminal ileum, the median density of apoptotic cells increased by 11-fold in follicular T-cell zones and by only 1.7-fold in GC at $14 \mathrm{dpi}$, as compared to controls (data not shown). These results indicate that apoptosis progresses with different kinetics in the inductive and effector mucosal compartments of SIVinfected animals.

\section{Decrease in plasma IgA despite increased BAFF production}

In contrast to increased plasma IgG and IgM levels observed in these macaques prior to $14 \mathrm{dpi}$ [32], plasma IgA levels progressively decreased from $18 \%$ on 14 dpi to $46 \%$ on $28 \mathrm{dpi}$ as compared to baseline values before infection (Figure 6A). Considering that BAFF and APRIL are important IgA inducing factors [13,35-37], we measured both of these cytokines in plasma. The median concentration of plasma APRIL, which was $22 \mathrm{ng} / \mathrm{ml}$ before infection, varied between 13 and $18 \mathrm{ng} / \mathrm{ml}$ after SIV infection (Figure 6B). In contrast, we observed a sharp increase in plasma BAFF that peaked at $11-12 \mathrm{dpi}(1,347 \mathrm{pg} / \mathrm{ml}$ versus $298 \mathrm{pg} / \mathrm{ml}$ before infection, 4.5 -fold increase), and remained elevated at $13-15 \mathrm{dpi}(918 \mathrm{pg} / \mathrm{ml}, 3.1$-fold increase) and decreased toward baseline values thereafter (Figure 6C). Throughout the acute phase of infection, BAFF levels correlated with plasma viral load $(p<0.0001)$ (Figure 6D) and inversely with circulating $\mathrm{CD} 4^{+} \mathrm{T}$-cell counts $(r h o=-0.596, p<0.0001)$ but not with plasma IgA (data not shown).

In an attempt to correlate increased plasma BAFF levels with its local production in lymphoid tissues, we compared BAFF expression in the intestinal mucosa of acutely SIV-infected and control macaques using Buffy2 mAb and immunohistochemical approach. Both isolated cells and stromal cell network associated with B-cell follicles, and GC were strongly stained by Buffy2 mAb (Figure 6E). The stromal network in T-cell areas immediately adjacent to B-cell follicles was also $\mathrm{BAFF}^{+}$. Our present results thus reveal increased BAFF production in intestinal mucosa even if additional experiments in SIV-infected macaques are needed to identify BAFF-producing cells in 


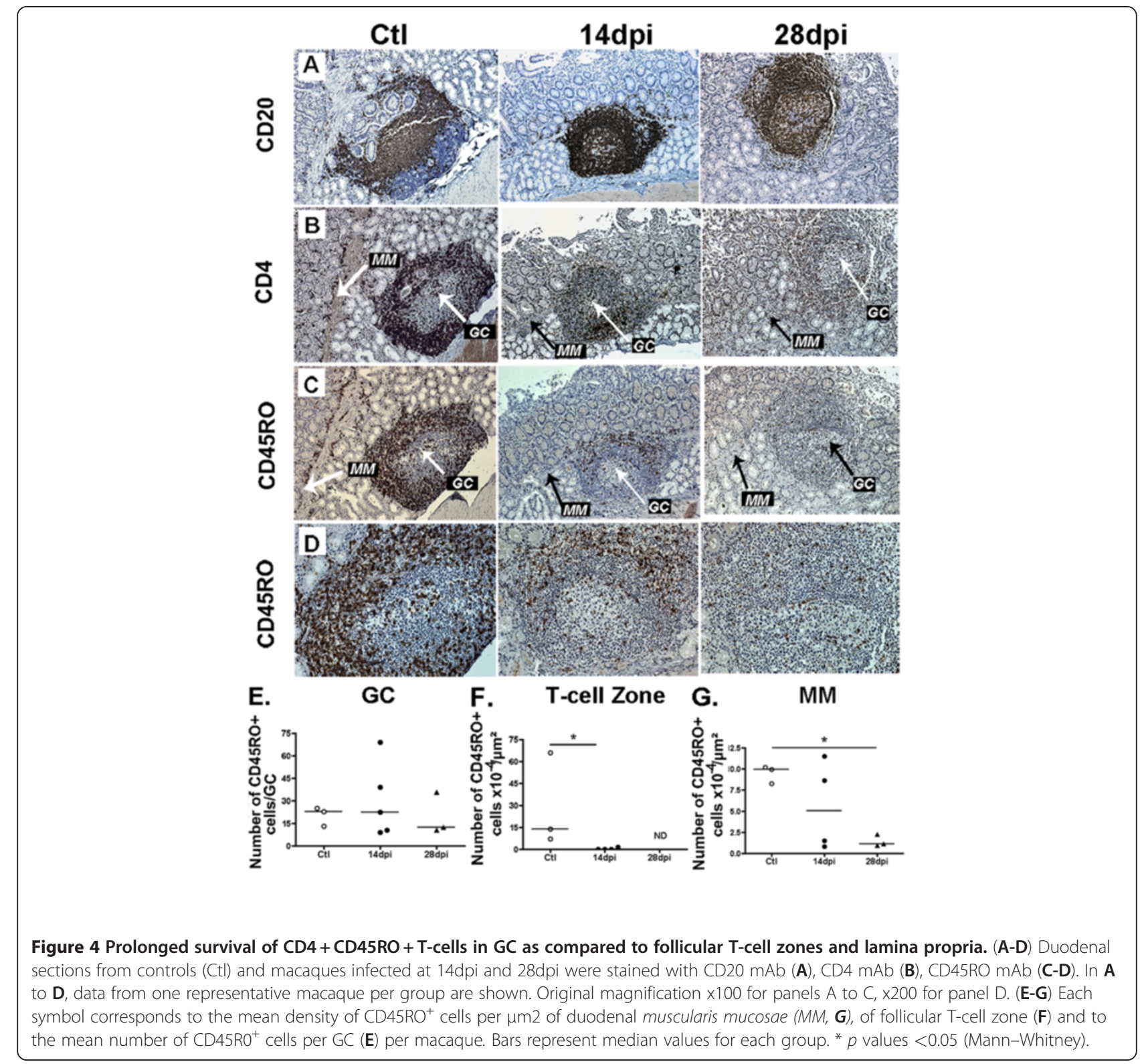

this microenvironment during SIV infection as well as to quantify the magnitude of BAFF overproduction in specific tissue areas. Thus, plasma IgA progressively decreases during acute SIV infection despite increased systemic and mucosal production of BAFF.

\section{Discussion}

Dysfunctions in circulating B-cells have been extensively described in chronically, and to a lesser extent, in primary HIV-infected patients [38-40]; but only very few studies have been devoted to mucosal B-cells during primary HIV infection [41]. This situation contrasts with the pivotal role of the intestinal mucosa as a major site of IgA response in healthy individuals as well as a site of intense and early virus replication, heavy damages to $\mathrm{CD}^{+}{ }^{+} \mathrm{T}$-cell subsets and chronic inflammation in HIV-infected individuals. Consistent with early inflammation described in pathogenic SIV/HIV infection, we observed overproduction of BAFF and infiltration of the intestinal mucosa by isolated lymphoid follicles, which progressively organized into secondary follicles containing well-developed GC (32 and this work). This increase in B-cell areas is consistent with increased proportions of B-cells within the ileal LP of primary HIVinfected patients reported by Levesque et al. [41]. In addition to PP, isolated lymphoid follicles constitute important sites for the IgA response against bacteria and are also associated with chronic inflammation in several disorders $[42,43]$. As previously observed in mesenteric lymph nodes of the same animals [32], a dominant IgG over IgA response was observed in GC of both PP and isolated 


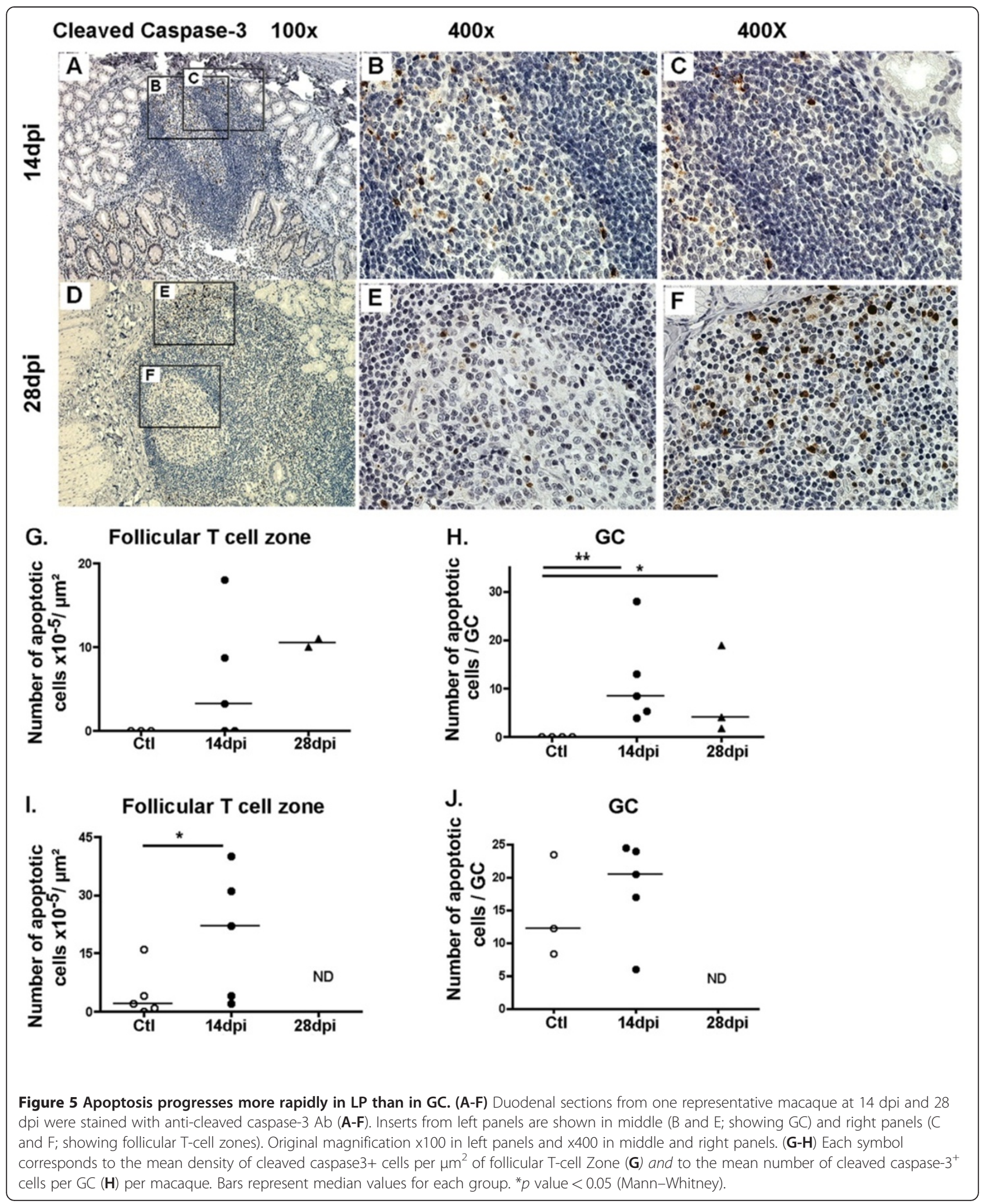

lymphoid follicles. The sustained generation of IgG plasmablasts in these GC that display a preserved polarization ([32] and Additional file 2: Figure S2) is in favor of functional GC, which nevertheless have lost the capacity to support T-dependent IgA response. In SIV-infected macaques, normal expression of Bcl6 and Ki67 by GC B-cells 
A.

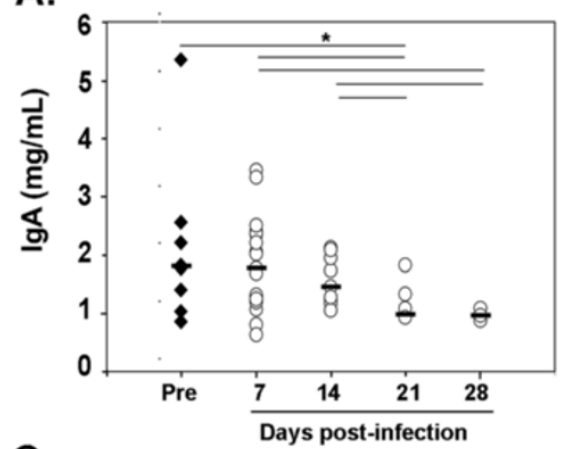

C.

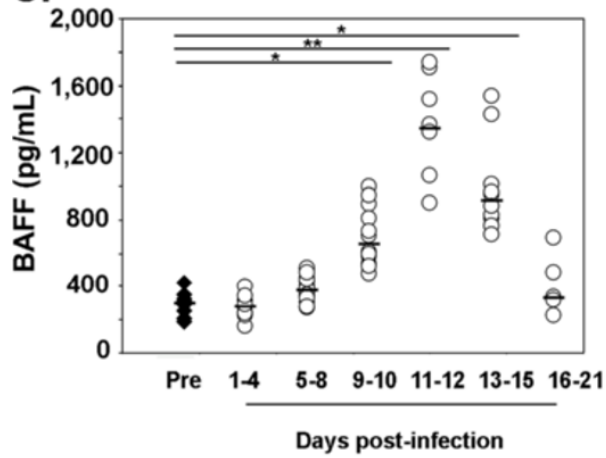

B.

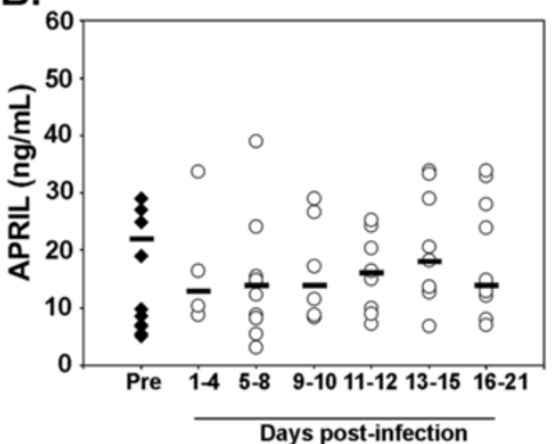

D.

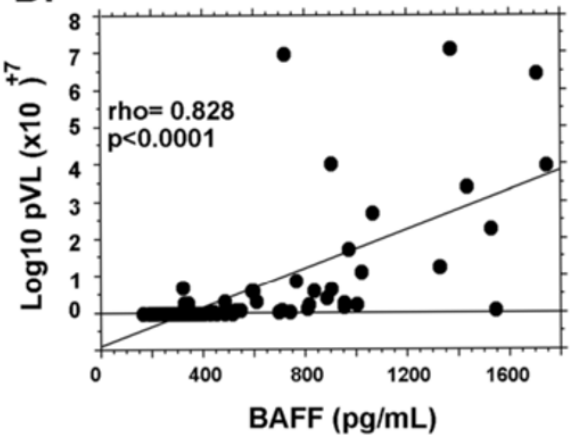

E.

CD20

BAFF (100x)

BAFF (400x)

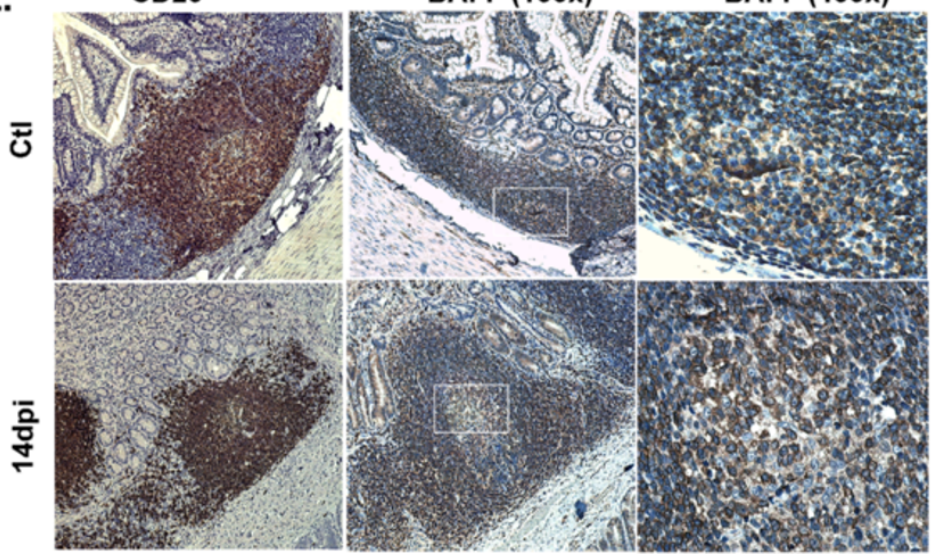

Figure 6 Decreased plasma IgA levels despite a strong increase in BAFF levels. (A) Plasma IgA levels were measured in SIV-infected macaques before infection (Pre; filled diamonds) and every $7 \mathrm{dpi}$ (open circles). Results are expressed in $\mathrm{mg} / \mathrm{mL}$ and bars represent median levels. Significant differences between groups are shown $\left({ }^{*} p<0.05\right)$. (B-C) APRIL and BAFF levels were measured in plasma from SIV-infected macaques, before (Pre: filled diamonds) and every 3 dpi (open circles). Results are expressed in pg/mL (BAFF) and ng/mL (APRIL), and bars represent median levels. Significant differences between groups are shown $\left({ }^{*} p<0.05,{ }^{* *} p<0.01\right)$. (D) Correlation between BAFF levels and plasma viral load (Log 10 $\mathrm{pVL}$ ) is shown. (E) lleum sections from control macaques (upper panel) and macaques infected for 14 days (lower panel) were stained with antiCD20 (B-cells, left panels) or anti-BAFF (Buffy2, middle and right panels) mAb. Original magnification: x200 for CD20, x100 and x400 for Buffy2.

(Additional file 2: Figure S2) suggests that decreased production of IL21 by follicular helper T-cells is likely not responsible for the lack of IgA plasma cells. The expression of these factors is under the control of IL21-IL21R interactions $[5,44]$. Because most systemic IgA are of T-dependent origin, the marked decrease in plasma IgA levels is consistent with the absence of IgA plasmablasts within GC. However, the precise mechanism underlying their absence within functional GC remains to be further investigated.

As compared to their accelerated death in LP and follicular T-cell zones, $\mathrm{CD}^{+}{ }^{+} \mathrm{CD} 45 \mathrm{RO}^{+}$T-cells were present within GC until $28 \mathrm{dpi}$, suggesting a prolonged survival 
within this special environment. This observation could be related to the low CCR5 expression on follicular helper Tcells, which might protect them from SIV infection [45]. A less dramatic loss of $\mathrm{CD}^{+}$T-cells in PP than in LP has been previously reported in SIV-infected monkeys $[2,46]$. Moreover, Zhang et al. have shown that early GC disruption (20 dpi) occurs preferentially after SIV infection of Indian rhesus monkeys, a model of rapid disease progression [47]. Aside from the results of Levesque et al. showing GC fragmentation in primary HIV-infected patients [39], involution of GC is more frequent during chronic and advanced phases of the disease when CXCR4 variants are present [31,48]. However, treatment of HIV-infected patients with CCR5 antagonists has shown that small populations of X4 variants are more frequently present during primary HIV infection than previously suspected [49]. When present, these variants might contribute to the infection of follicular helper T-cells expressing CXCR4 and, hence, to their apoptosis [45].

Because of the presence of follicular helper T-cells and appropriate GC organization, other mechanisms could account for the lack of T-dependent IgA response within GC. Among other possibilities, a decreased production of active TGF $\beta 1$ or retinoic acids associated with impaired activation of intestinal dendritic cells might reduce the IgA response $[50,51]$. Interestingly, differential kinetics of TGF $\beta 1$ production and responsiveness to TGF $\beta 1$ distinguish pathogenic from non-pathogenic SIV infections [52,53]. The frequency of TGF $\beta$-positive cells also increases in the peripheral or mesenteric lymph nodes of SIVmac-infected rhesus macaques but not in those of African green monkeys or sooty

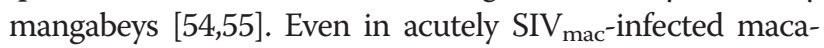
ques where $\mathrm{TGF} \beta^{+}$cells accumulate in paracortical T-cell zones of lymph nodes with a peak at 11-16dpi, these cells were absent from GC of B-cell follicles. Whether the lack of TGF $\beta^{+}$cells reflects impaired T-cell production in SIVinfected animals or normal low levels of TGF within GC remains to be clarified. In addition, the absence of newly generated IgA plasmablasts at the benefit of IgG and IgM ones as well as the rapid loss of $\mathrm{CD} 4^{+} \mathrm{T}$-cells within the LP, likely participates to decrease the proportions of IgA plasma cells in this effector site.

\section{Conclusion}

Our data point to a generalized default in IgA response, already detectable during the acute phase of infection. The understanding of mechanisms causing this impaired IgA response during HIV/SIV infection is crucial in order to improve the mucosal virus-specific response and control microbial translocation. Considering the importance of mucosal defenses in determining the host-pathogen balanced relationship [56-58], it remains to be established whether the early default in the T-dependent IgA response similarly occurs after infection by mucosal routes which represent the more frequent routes of HIV infection.

\section{Methods}

\section{Animals and ethics statement}

Mauritian adult male Cynomolgus macaques (Macaca fascicularis), weighing 4 to $6 \mathrm{~kg}$, were housed each in single cages within level 3 biosafety facilities. Animals were housed and cared for in accordance with the European Guidelines for Animal Care ("Journal officiel des Communautés Européennes" L358, 18 décembre 1986). A regional Animal Care and Use Committee: "Comité Régional d'Ethique sur l'expérimentation animale Ile-deFrance Sud", reviewed and approved all protocols, with the goal of improving animal welfare and limiting unnecessary suffering. The animals were sedated with Ketamine chlorydrate (Rhone-Merieux, Lyon, France) before virus injection, blood sample collection or euthanasia. The animals were inoculated intravenously with 50 AID50 SIVmac251 and were euthanized at 14 (five animals), 21 (five animals) and 28 (three animals) days post-infection (dpi). Blood samples were collected before infection and every 3 dpi thereafter until euthanasia. Plasma samples were kept at $-80^{\circ} \mathrm{C}$ until use. Changes in plasma viral load, $\mathrm{CD} 4^{+} \mathrm{T}$-cell counts, circulating and tissue-specific B-cell subsets of these SIV-infected macaques have been previously reported [32]. After euthanasia, duodenal and terminal ileum tissue samples (corresponding to a five $\mathrm{cm}$ section before the caecum) were formalin-fixed and paraffin-embedded. Control tissues were collected from three non-infected animals.

\section{Quantification of immunoglobulin A and cytokines}

Plasma BAFF and APRIL levels were respectively quantified using the Quantikine ${ }^{\circledR}$ ELISA kit for human BAFF/ BLyS (R\&D systems, Abingdon, UK) and APRIL human ELISA from Bender Medsystems (Tebu-Bio, Le Perray en Yvelines, France) according to the manufacturer's instructions. Plasma IgA concentrations were determined using a monkey IgA ELISA kit (Alpha diagnostic Intl Inc., San Antonio, Tx). Each sample was run in duplicate and results expressed as mean concentration (pg/ $\mathrm{mL}$ for BAFF, $\mathrm{ng} / \mathrm{mL}$ for APRIL and $\mathrm{mg} / \mathrm{ml}$ for $\operatorname{IgA}) \pm$ SD for each animal and at each time point.

\section{Immunohistochemistry (IHC) and image analysis}

All paraffin-embedded tissues were cut into $(3 \mu \mathrm{m})$ sections, perpendicularly to the intestinal wall so that each intestinal compartment could be examined. After antigen retrieval in sodium citrate (pH6) (CD20, Ki67, Buffy2), EDTA (pH 9) (CD3) or EDTA (pH 8) (other Ab), sections were then labeled with optimized concentrations of monoclonal or polyclonal antibodies against: CD20 (L26), IRF4 (MUM-1P), IgA (rabbit F(ab') $)_{2}$, IgG (rabbit $\mathrm{F}\left(\mathrm{ab}^{\prime}\right)_{2}$, 
IgM (rabbit $\mathrm{F}\left(\mathrm{ab}^{\prime}\right)_{2}, \mathrm{CD} 45 \mathrm{R} 0$ (OPD4), and CD68 (clone KP1) (all from Dako, Glosturp, Danemark), CD4 (1 F6) and CD23 (1B12) (from Novocastra, Newcastle, UK), Ki67 (MIB5, Beckman Coulter, Fullerton), CD3 (SP34-2, Becton Dickinson, Franklin Lakes, NJ) and cleaved caspase-3 (rabbit serum, Cell Signaling Technology Inc., Danvers, MA). Polyclonal Ig and mouse isotype controls were from Dako or R\&D systems. Antibody binding was visualized with the Novolink anti-rabbit/mouse secondary Ab Polymer kit (Novocastra Laboratories, Newcastle upon Tyne, UK) according to the manufacturer's instructions. Binding of Buffy2 mAb (Enzo life Sciences, Villeurbanne, France) was visualized by the EnVision ${ }^{\mathrm{m}}+$ Dual Link Kit from Dako. Nuclei were counter-stained with Hematoxylin QS (Vector Laboratories, Burlingame, CA). Digital images of tissue sections were captured without manipulation using a Zeiss Microscope (Axiophot 2) coupled to a Microfire camera (Optronics, CA) and using the MorphoLite software (Explora Nova, La Rochelle, France).

Image analysis was performed with the Mercator 4.42 software (Explora Nova) on tissue sections from three noninfected animals as controls and from SIV-infected animals euthanized at either 14 or 28 dpi. Epithelium was outlined by hand and excluded in each field. Area from muscularis mucosae to tips of villi was referred to as "total mucosa" whereas $\mathrm{CD}^{+} \mathrm{T}$-cell areas surrounding B-cell areas, including isolated lymphoid follicles and B-cell follicles in PP, were referred to as "follicular T-cell zones" throughout the manuscript. The LP was defined as total mucosa minus follicular T-cell zones and B-cell areas. The number of B-cell areas was determined by counting $\mathrm{CD}_{2} 0^{+}$areas in total mucosa at 100X magnification, corresponding to surface areas of 9,467 to 308,392 (duodenum) and 8,000 to 12,409 (ileum) $\mu \mathrm{m}^{2}$. Data are expressed as the average number of B-cell areas per $\mu \mathrm{m}^{2}$ of total mucosa. Immunoreactive cells were counted in all GC present in every section at 100X magnification. By using the Novolink anti-rabbit/mouse secondary Ab Polymer kit, we experienced limited difficulties in discriminating Ig-producing cells from the reticular background possibly observed in GC or sub-epithelial areas. Accordingly, only cells with a clear cytoplasmic staining were taken into account for quantification. Data are expressed as mean $( \pm \mathrm{SD})$ number of positive cells per GC. Immunoreactive cells were counted in follicular $\mathrm{T}$-cell zones, muscularis mucosae (MM) or LP by analyzing as many fields as possible at 100X magnification. Surface areas of 7,900 to 112,172 (duodenum) and 6,167 to 161,140 (ileum) $\mu \mathrm{m}^{2}$ for follicular T-cell zones; 1,182 to 71,742 (duodenum) and 29,000 to 51,500 (ileum) $\mu \mathrm{m}^{2}$ for muscularis mucosae; 147,000 to 900,000 (duodenum) and 235,000 to 750,000 (Ileum) $\mu \mathrm{m}^{2}$ for LP were analyzed. Data are expressed as the mean density of immunoreactive cells (number of positive cells $( \pm \mathrm{SD}) / \mathrm{mm}^{2}$ ).

\section{Statistical analyses}

Non-parametric Wilcoxon's test or Mann-Whitney's test (two-tailed unless otherwise indicated) and correlations (Spearman's rank test) were assessed using the GraphPad Prism 5 software (La Jolla, CA). $p$ values $<0.05$ were considered as significant.

\section{Additional files}

\begin{abstract}
Additional file 1: Figure S1. Acute SIV-Infection changes the density of $\lg A, \lg G$ and igM plasma cells in the intestinal LP. The relative proportions of $\lg A$, IgG and IgM plasma cells in the LP of duodenum (A) or ileum (B) were calculated, for each group of macaques, as the ratio between the median numbers of positive cells for one isotype to the median number of total plasma cells $\times 100$.

Additional file 2: Figure S2. Preserved polarization of GC in SIVinfected macaques. (A-D) Duodenum sections from controls (Ctl; left panel) and macaques infected for $14 \mathrm{dpi}$ (middle panel) and $28 \mathrm{dpi}$ (right panel) were stained with CD20 (A), CD23 (B), Ki67 (C) and CD68 (D) Ab. Stained sections from one representative macaque per group are shown. Original magnification: x100 for all panels. Because T-dependent response is strongly dependent on GC, we analyzed the GC organization after SIV infection. CD23 mAb strongly stains mature FDC network of the light zone, while Ki67 Ab stains proliferating B-cells present in the dark zone and helper T-cells in the light zone. ILF without GC in the duodenal mucosa of controls were stained by CD20 mAb (A) but not by Ki67 mAb (C). In the absence of typical GC-like structures, CD23 mAb consistently stained the network of stromal cells in these ILF (B). After SIV-infection, GC progressively developed in B-cell follicles with numerous $\mathrm{Ki}_{67}{ }^{+}$cells on $14 \mathrm{dpi}$ and a strong staining of a patchy FDC network. On $28 \mathrm{dpi}$, GCs were clearly hyperplasic but still correctly polarized as shown by Ki67 staining (C). The increase in Ki67 ${ }^{+}$cells (B-cells and helper T-cells) within the GC in SIV-infected macaques was concomitant with T-cell activation in the LP and T-cell zones. Whereas rare $\mathrm{CD}^{+} 8^{+}$macrophages were present within B-cell follicles in controls, they were consistently present in GC at 14 and 28 dpi. We observed similar changes for CD23 and Ki67 staining in terminal ileum (data not shown).
\end{abstract}

\section{Abbreviations}

Ab: antibody (ies); APRIL: a proliferation-Inducing ligand; BAFF: B-cell activating factor of the TNF family; Dpi: days post-infection; GC: germinal center(s); HIV: human Immunodeficiency Virus; Ig: immunoglobulin(s); ILF: isolated lymphoid follicles; LP: lamina propria; PP: Peyer's Patches; SIV: Simian Immunodeficiency Virus.

\section{Competing interests}

The authors declare that they have no competing interests.

\section{Acknowledgements}

The authors thank the CEA technical staff for animal care and DVM C. Joubert. We thank P. Brochard and B. Delache for collecting blood and intestinal biopsies.

\section{Author details}

${ }^{1}$ Commissariat à I'Energie Atomique (CEA), CEA, Institut des Maladies Emergentes et Thérapies Innovantes Service d'Immuno-Virologie, CEA, Fontenay-aux Roses, F-92260, France. ' Université Paris-Sud, Orsay, F-91060, France. ${ }^{3}$ EA3064 Université de Lyon, Faculté de Médecine et Etablissement Français du Sang (EFS) Auvergne-Loire, Saint Etienne, F-42023, France. ${ }^{4}$ Service d'Anatomie et Cytologie pathologiques, AP-HP, Hôpital A. Béclère, Clamart, F-92140, France. ${ }^{5}$ Université Paris-Sud, Faculté de Médecine, Le Kremlin-Bicêtre, F-94276, France. 'Service d'Hématologie et Immunologie Biologiques, cytogénétique, CHU-Bicêtre, Assistance Publique-Hôpitaux de Paris (AP-HP), Le Kremlin-Bicêtre, F-94 724, France. ${ }^{7}$ INSERM U802, Université Paris-Sud, Le Kremlin-Bicêtre, F-94 724, France. ${ }^{8}$ Inserm U1016, Institut Cochin, Paris, France. ${ }^{9} \mathrm{CNRS}$ UMR8104, Paris, France. Institut Cochin. Département d'Immunologie. 27, Rue du Faubourg St Jacques, Paris, F75014, France. 


\section{Financial support}

This work was supported by grants from the Agence Nationale de Recherche sur le SIDA et les Hépatites Virales (ANRS) (\#23-1209 to YR) and the Fondation de la Recherche Médicale (\#2006-0306369 to YR). NC and SP were PhD fellows of Europrise Network of Excellence and ANRS, respectively. The Centre National de la Recherche Scientifique (CNRS) supports YR.

Received: 13 February 2012 Accepted: 25 May 2012

Published: 25 May 2012

\section{References}

1. Brenchley JM, Schacker TW, Ruff LE, Price DA, Taylor JH, Beilman GJ, Nguyen PL, Khoruts A, Larson M, Haase AT, et al: CD4+ T cell depletion during all stages of HIV disease occurs predominantly in the gastrointestinal tract. J Exp Med 2004, 200(6):749-759.

2. Veazey RS, DeMaria M, Chalifoux LV, Shvetz DE, Pauley DR, Knight HL, Rosenzweig M, Johnson RP, Desrosiers RC, Lackner AA: Gastrointestinal tract as a major site of CD4+ T cell depletion and viral replication in SIV infection. Science 1998, 280(5362):427-431.

3. Suzuki K, Fagarasan S: How host-bacterial interactions lead to IgA synthesis in the gut. Trends Immunol 2008, 29(11):523-531.

4. Fagarasan S, Honjo T: Intestinal IgA synthesis: regulation of front-line body defences. Nat Rev Immunol 2003, 3(1):63-72

5. Ozaki K, Spolski R, Feng CG, Qi CF, Cheng J, Sher A, Morse HC, Liu C 3rd, Schwartzberg PL, Leonard WJ: A critical role for IL-21 in regulating immunoglobulin production. Science 2002, 298(5598):1630-1634.

6. Cerutti A: The regulation of IgA class switching. Nat Rev Immunol 2008, 8(6):421-434.

7. Cazac BB, Roes J: TGF-beta receptor controls $B$ cell responsiveness and induction of IgA in vivo. Immunity 2000, 13(4):443-451.

8. Macpherson AJ, McCoy KD, Johansen FE, Brandtzaeg P: The immune geography of IgA induction and function. Mucosal Immunol 2008, 1(1):11-22.

9. Cerutti $A$, Rescigno M: The biology of intestinal immunoglobulin $A$ responses. Immunity 2008, 28(6):740-750.

10. Aloisi F, Pujol-Borrell R: Lymphoid neogenesis in chronic inflammatory diseases. Nat Rev Immunol 2006, 6(3):205-217.

11. Mackay F, Schneider P, Rennert P, Browning J: BAFF AND APRIL: a tutorial on B cell survival. Annu Rev Immunol 2003, 21:231-264.

12. Jain A, Ma CA, Lopez-Granados E, Means G, Brady W, Orange JS, Liu S, Holland S, Derry JM: Specific NEMO mutations impair CD40-mediated c-Rel activation and B cell terminal differentiation. J Clin Invest 2004, 114(11):1593-1602.

13. He B, Xu W, Santini PA, Polydorides AD, Chiu A, Estrella J, Shan M, Chadburn A, Villanacci V, Plebani A, et al: Intestinal bacteria trigger T cellindependent immunoglobulin $\mathrm{A}(2)$ class switching by inducing epithelial-cell secretion of the cytokine APRIL. Immunity 2007, 26(6):812-826

14. Peppard J, Kaetzel C, Russell M: Phylogeny and comparative physiolgy of IgA in Mucosal Immunology 3rd Ed. In Mucosal Immunology. Volume 1, ednth edition. Edited by Mestecky JOP, McGhee JR, Lambrecht BN, Strober W. Amsterdam: Elsevier Science-Academic Press; 2005:195-210.

15. Scinicariello F, Attanasio R: Intraspecies heterogeneity of immunoglobulin alpha-chain constant region genes in rhesus macaques. Immunology 2001, 103(4):441-448.

16. Mestecky J, Wright PF, Lopalco L, Staats HF, Kozlowski PA, Moldoveanu Z, Alexander RC, Kulhavy R, Pastori C, Maboko L, et al: Scarcity or absence of humoral immune responses in the plasma and cervicovaginal lavage fluids of heavily HIV-1-exposed but persistently seronegative women. AIDS Res Hum Retroviruses 2011, 27(5):469-486.

17. Devito C, Broliden K, Kaul R, Svensson L, Johansen K, Kiama P, Kimani J, Lopalco L, Piconi S, Bwayo JJ, et al: Mucosal and plasma IgA from HIV-1exposed uninfected individuals inhibit HIV-1 transcytosis across human epithelial cells. J Immunol 2000, 165(9):5170-5176.

18. Tudor D, Derrien M, Diomede L, Drillet AS, Houimel M, Moog C, Reynes JM, Lopalco L, Bomsel M: HIV-1 gp41-specific monoclonal mucosal IgAs derived from highly exposed but IgG-seronegative individuals block HIV1 epithelial transcytosis and neutralize CD4(+) cell infection: an IgA gene and functional analysis. Mucosal Immunol 2009, 2(5):412-426.
19. Barassi C, Lazzarin A, Lopalco L: CCR5-specific mucosal IgA in saliva and genital fluids of HIV-exposed seronegative subjects. Blood 2004, 104(7):2205-2206.

20. Nilssen DE, Oktedalen $\mathrm{O}$, Brandtzaeg P: Intestinal B cell hyperactivity in AIDS is controlled by highly active antiretroviral therapy. Gut 2004, 53(4):487-493

21. Bishop PE, McMillan A, Gilmour HM: Immunological study of the rectal mucosa of men with and without human immunodeficiency virus infection. Gut 1987, 28(12):1619-1624.

22. Kotler DP, Scholes JV, Tierney AR: Intestinal plasma cell alterations in acquired immunodeficiency syndrome. Dig Dis Sci 1987, 32(2):129-138

23. Raux M, Finkielsztejn L, Salmon-Ceron D, Bouchez H, Excler JL, Dulioust E, Grouin JM, Sicard D, Blondeau C: Comparison of the distribution of IgG and IgA antibodies in serum and various mucosal fluids of HIV type 1infected subjects. AIDS Res Hum Retroviruses 1999, 15(15):1365-1376.

24. Schneider T, Zippel T, Schmidt W, Pauli G, Wahnschaffe U, Chakravarti S, Heise W, Riecken EO, Zeitz M, Ullrich R: Increased immunoglobulin G production by short term cultured duodenal biopsy samples from HIV infected patients. Gut 1998, 42(3):357-361.

25. Scamurra RW, Nelson DB, Lin XM, Miller DJ, Silverman GJ, Kappel T, Thurn JR, Lorenz E, Kulkarni-Narla A, Janoff EN: Mucosal plasma cell repertoire during HIV-1 infection. J Immunol 2002, 169(7):4008-4016.

26. Schafer F, Kewenig S, Stolte N, Stahl-Hennig C, Stallmach A, Kaup FJ, Zeitz M, Schneider T: Lack of simian immunodeficiency virus (SIV) specific IgA response in the intestine of SIV infected rhesus macaques. Gut 2002, 50(5):608-614

27. McElrath J, Miller CJ: Mucosal Immunity and vaccines against SIV and HIV in Mucosal Immunolgy 3rd Ed. In Mucosal Immunology Volume 1. 3 ednth edition. Edited by Mestescky JOP, McGhee JR, Lambrecht BN, Strober W. Amsterdam: Elsevier Science-Academic Press; 2005:937-958.

28. Epple HJ, Schneider T, Troeger H, Kunkel D, Allers K, Moos V, Amasheh M, Loddenkemper C, Fromm M, Zeitz M, et al: Impairment of the intestinal barrier is evident in untreated but absent in suppressively treated HIVinfected patients. Gut 2009, 58(2):220-227.

29. Brenchley JM, Douek DC: The mucosal barrier and immune activation in HIV pathogenesis. Curr Opin HIV AIDS 2008, 3(3):356-361.

30. Sankaran S, Guadalupe M, Reay E, George MD, Flamm J, Prindiville T, Dandekar S: Gut mucosal T cell responses and gene expression correlate with protection against disease in long-term HIV-1-infected nonprogressors. Proc Natl Acad Sci U S A 2005, 102(28):9860-9865.

31. Xu W, Santini PA, Sullivan JS, He B, Shan M, Ball SC, Dyer WB, Ketas TJ, Chadburn A, Cohen-Gould L, et al: HIV-1 evades virus-specific IgG2 and IgA responses by targeting systemic and intestinal B cells via long-range intercellular conduits. Nat Immunol 2009, 10(9):1008-1017.

32. Peruchon S, Chaoul N, Burelout C, Delache B, Brochard P, Laurent P, Cognasse F, Prevot S, Garraud O, Le Grand R, et al: Tissue-specific B-cell dysfunction and generalized memory B-cell loss during acute SIV infection. PLoS One 2009, 4(6):e5966.

33. Jego G, Palucka AK, Blanck JP, Chalouni C, Pascual V, Banchereau J: Plasmacytoid dendritic cells induce plasma cell differentiation through type I interferon and interleukin 6. Immunity 2003, 19(2):225-234.

34. Shaffer AL, Emre NC, Romesser PB, Staudt LM: IRF4: Immunity. Malignancy! Therapy?. Clinical cancer research: an official journal of the American Association for Cancer Research 2009, 15(9):2954-2961

35. Castigli E, Scott S, Dedeoglu F, Bryce P, Jabara H, Bhan AK, Mizoguchi E, Geha RS: Impaired IgA class switching in APRIL-deficient mice. Proc Natl Acad Sci U S A 2004, 101(11):3903-3908.

36. Hardenberg G, van Bostelen L, Hahne M, Medema JP: Thymusindependent class switch recombination is affected by APRIL. Immunol Cell Biol 2008, 86(6):530-534.

37. Litinskiy MB, Nardelli B, Hilbert DM, He B, Schaffer A, Casali P, Cerutti A: DCs induce CD40-independent immunoglobulin class switching through BLyS and APRIL. Nat Immunol 2002, 3(9):822-829.

38. De Milito A: B lymphocyte dysfunctions in HIV infection. Curr HIV Res 2004, 2(1):11-21

39. Hart M, Steel A, Clark SA, Moyle G, Nelson M, Henderson DC, Wilson R, Gotch F, Gazzard B, Kelleher P: Loss of discrete memory B cell subsets is associated with impaired immunization responses in HIV-1 infection and may be a risk factor for invasive pneumococcal disease. J Immunol 2007, 178(12):8212-8220 
40. Titanji K, Chiodi F, Bellocco R, Schepis D, Osorio L, Tassandin C, Tambussi G, Grutzmeier S, Lopalco L, De Milito A: Primary HIV-1 infection sets the stage for important B lymphocyte dysfunctions. AIDS 2005, 19(17):1947-1955.

41. Levesque MC, Moody MA, Hwang KK, Marshall DJ, Whitesides JF, Amos JD, Gurley TC, Allgood S, Haynes BB, Vandergrift NA, et al: Polyclonal B cell differentiation and loss of gastrointestinal tract germinal centers in the earliest stages of HIV-1 infection. PLoS Med 2009, 6(7):e1000107.

42. Hamada H, Hiroi T, Nishiyama Y, Takahashi H, Masunaga Y, Hachimura S, Kaminogawa S, Takahashi-Iwanaga $\mathrm{H}$, Iwanaga $\mathrm{T}$, Kiyono $\mathrm{H}$, et al: Identification of multiple isolated lymphoid follicles on the antimesenteric wall of the mouse small intestine. J Immunol 2002, 168(1):57-64.

43. Tsuji M, Suzuki K, Kitamura H, Maruya M, Kinoshita K, Ivanov II, Itoh K Littman DR, Fagarasan S: Requirement for lymphoid tissue-inducer cells in isolated follicle formation and T cell-independent immunoglobulin A generation in the gut. Immunity 2008, 29(2):261-271.

44. Vogelzang A, McGuire HM, Yu D, Sprent J, Mackay CR, King C: A fundamental role for interleukin-21 in the generation of $\mathrm{T}$ follicular helper cells. Immunity 2008, 29(1):127-137.

45. Schaerli P, Willimann K, Lang AB, Lipp M, Loetscher P, Moser B: CXC chemokine receptor 5 expression defines follicular homing T cells with $B$ cell helper function. J Exp Med 2000, 192(11):1553-1562.

46. Vajdy M, Veazey RS, Knight HK, Lackner AA, Neutra MR: Differential effects of simian immunodeficiency virus infection on immune inductive and effector sites in the rectal mucosa of rhesus macaques. Am J Pathol 2000, 157(2):485-495.

47. Zhang ZQ, Casimiro DR, Schleif WA, Chen M, Citron M, Davies ME, Burns J, Liang X, Fu TM, Handt L, et al: Early depletion of proliferating B cells of germinal center in rapidly progressive simian immunodeficiency virus infection. Virology 2007, 361(2):455-464.

48. Legendre C, Raphael M, Gras G, Lefevre EA, Feuillard J, Dormont D, Richard $Y:$ CD80 expression is decreased in hyperplastic lymph nodes of HIV + patients. Int Immunol 1998, 10(12):1847-1851.

49. Frange P, Galimand J, Goujard C, Deveau C, Ghosn J, Rouzioux C, Meyer L, Chaix ML: High frequency of X4/DM-tropic viruses in PBMC samples from patients with primary HIV-1 subtype-B infection in 1996-2007: the French ANRS CO06 PRIMO Cohort Study. J Antimicrob Chemother 2009, 64(1):135-141.

50. Mora JR, Iwata M, Eksteen B, Song SY, Junt T, Senman B, Otipoby KL, Yokota A, Takeuchi H, Ricciardi-Castagnoli $P$, et al: Generation of gut-homing IgAsecreting B cells by intestinal dendritic cells. Science 2006, 314(5802):1157-1160.

51. Tezuka H, Abe $Y$, Iwata M, Takeuchi H, Ishikawa H, Matsushita M, Shiohara T, Akira S, Ohteki T: Regulation of IgA production by naturally occurring TNF/iNOS-producing dendritic cells. Nature 2007, 448(7156):929-933.

52. Kornfeld C, Ploquin MJ, Pandrea I, Faye A, Onanga R, Apetrei C, PoatyMavoungou V, Rouquet $P$, Estaquier J, Mortara L, et al: Antiinflammatory profiles during primary SIV infection in African green monkeys are associated with protection against AIDS. J Clin Invest 2005, 115(4):1082-1091.

53. Ploquin MJ, Desoutter JF, Santos PR, Pandrea I, Diop OM, Hosmalin A, Butor C, Barre-Sinoussi F, Muller-Trutwin MC: Distinct expression profiles of TGFbeta1 signaling mediators in pathogenic SIVmac and non-pathogenic SIVagm infections. Retrovirology 2006, 3:37.

54. Campillo-Gimenez L, Cumont MC, Fay M, Kared H, Monceaux V, Diop O, Muller-Trutwin M, Hurtrel B, Levy Y, Zaunders J, et al: AIDS progression is associated with the emergence of IL-17-producing cells early after simian immunodeficiency virus infection. J Immunol 2010, 184(2):984-992.

55. Estes JD, Wietgrefe S, Schacker T, Southern P, Beilman G, Reilly C, Milush JM, Lifson JD, Sodora DL, Carlis JV, et al: Simian immunodeficiency virusinduced lymphatic tissue fibrosis is mediated by transforming growth factor beta 1-positive regulatory $T$ cells and begins in early infection. $J$ Infect Dis 2007, 195(4):551-561.

56. Haase AT: Perils at mucosal front lines for HIV and SIV and their hosts. Nat Rev Immunol 2005, 5(10):783-792.

57. Shacklett BL: Immune responses to HIV and SIV in mucosal tissues: 'location, location, location'. Curr Opin HIV AIDS 2010, 5(2):128-134.
58. Schultheiss T, Schulte R, Sauermann U, Ibing W, Stahl-Hennig C: Strong mucosal immune responses in SIV infected macaques contribute to viral control and preserved CD4+ T-cell levels in blood and mucosal tissues. Retrovirology 2011, 8:24.

doi:10.1186/1742-4690-9-43

Cite this article as: Chaoul et al:: Default in plasma and intestinal lgA responses during acute infection by simian immunodeficiency virus. Retrovirology 2012 9:43.

\section{Submit your next manuscript to BioMed Central and take full advantage of:}

- Convenient online submission

- Thorough peer review

- No space constraints or color figure charges

- Immediate publication on acceptance

- Inclusion in PubMed, CAS, Scopus and Google Scholar

- Research which is freely available for redistribution 